\title{
CLASSROOM INTERACTION ANALYSIS OF ENGLISH CLASS IN SMPN 2 BABALAN
}

\author{
AN ARTICLE \\ Submttited in Partial Fulfillment of the Requirements \\ for the Degree of Sarjana Pendidikan
}

By:

KRISMAN SIPAHUTAR

Registration Number: 2123121026

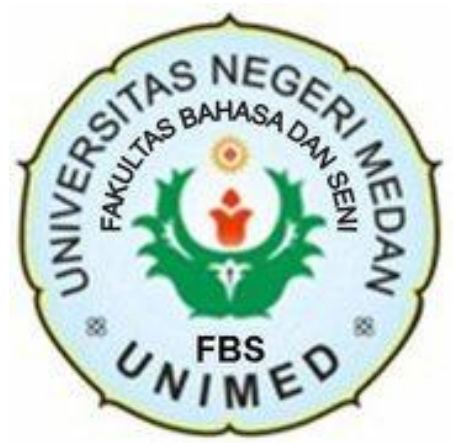

ENGLISH AND LITERATURE DEPARTMENT

FACULTY OF LANGUAGES AND ARTS

STATE UNIVERSITY OF MEDAN

2017 
ARTIKEL

\section{CLASSROOM INTERACTION ANALYSIS OF ENGLISH CLASS IN SMPN 2}

BABALAN

Disusun dan Diajukan oleh:

Krisman Sipahutar

NIM. 2123121026

Telah diverifikasi dan dinyatakan memenuhi syarat Untuk diunggah pada jurnal online

Medan, Juli 2017

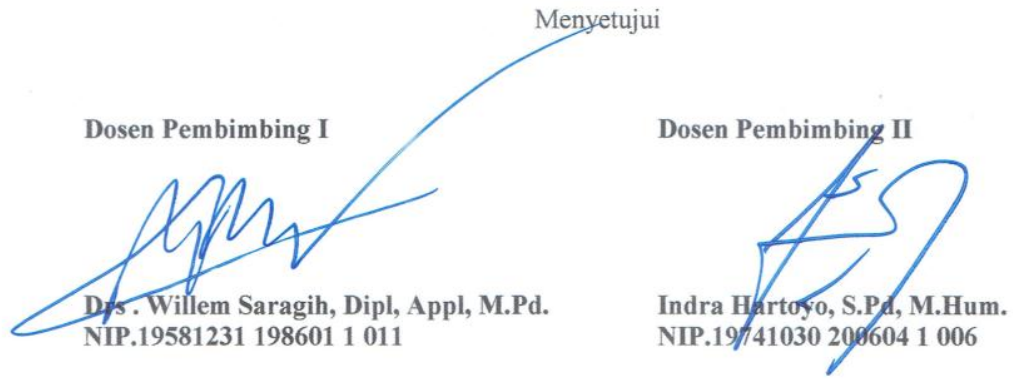

Ka. Program Studi Pendidikan Bahasa Inggris

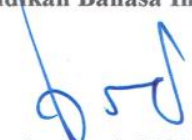

Nora Ronita Dewi, S.Pd., S.S., M.Hum.

NIP. 198005522008122003 


\title{
CLASSROOM INTERACTION ANALYSIS OF ENGLISH
}

\author{
CLASS IN SMPN 2 BABALAN
}

\author{
*Krisman Sipahutar \\ **Willem Saragih \\ **Indra Hartoyo
}

\begin{abstract}
Sipahutar, Krisman. NIM 2123121026. Classroom Interaction Analysis of English Class In SMP N 2 Babalan. A Thesis. Faculty of Languages And Arts, State University of Medan. 2017.

The purpose of this study was to find out the types of interaction, the percentage of teacher talk and student talk and the dominant characteristic of interaction which appeared during teaching-learning process in SMP $\mathrm{N} 2$ Babalan in 2016/2017 academic year. This study used descriptive design. The subjects of this study were three classes. One class of the eighth grade and two classes of the nineth grade. The data were analyzed by using Flanders Interaction Analysis Category System (FIACS). The instruments of collecting data were audio and video recording. The analysis showed that all of the ten types of interaction appeared. The percentages of each types of interaction were: (a) accepting feeling: 0.41\%; (b) praising and encouraging: $9.97 \%$; (c) accepting students' ideas: $0.22 \%$; (d) asking question: 26.26\%; (e) lecturing: 4.70\%; (f) giving direction: $13.25 \%$; (g) criticizing: $2.21 \%$; (h) tudents talk response: $39.35 \%$; (i) student talk initiation: $1.10 \%$; (j) silence and confusion: $1.93 \%$. Teacher talk percentages were $60.98 \%$ in class $8-1,51.62 \%$ in class $9-2$ and $61.15 \%$ in class $9-5$. And the student talk percentages were $37.31 \%$ in class $8-1,47.29 \%$ in class $9-2$ and $20.09 \%$ in class 95 . The dominant characteristic of interaction was content cross, which means that the teacher focused on giving questions and giving materials. From the results, the researcher concluded that the teacher was dominant in the classroom during the teaching-learning processes.
\end{abstract}

Keywords: Classroom Interaction, Flanders Interaction Analysis Category System (FIACS). Teacher talk, Student talk.

\footnotetext{
*Graduate status

** Lecturer status
} 


\section{INTRODUCTION}

Background of the Study

Language is a type of behaviour, that it is a state of mind, and that it is a means of communication (Siobhan, 2006:25). The function of language itself is to transfer information or messages and expressideas and emotions.In education, English has become the primary language of communication. It is very important for foreign language learners to use English in the class. Additionally, EFL students are required to practice the language in the classroom as much as possible. Because of that, the teachers should give more chances for the students to speak up in the classroom to create some interactions during having a class.

Classroom interaction that is intended in this research is how the teacher and students participate to talk during teaching and learning process. In fact, according to Wang (2015) the amount of the teacher talk is still higher than the students in English classroom teaching. Nunan in Pujiastuti (2013) said that many language teachers were surprised of the amount of talk they used in classroom. About 70 to 80 percents out of class time was spent mostly by teacher talk.

As Ildiko (2010) said that Teacher Talk (TT) is the language typically used by foreign language teachers in the process of teaching, it is not a one-way speech but it also engages the students, so, teacher does not talk all the time during the lesson. Davies (2011) said that teachers who 'work' too much in the classroom were not teaching successfully. He mentioned that a good language teacher is able to 'get students to do more work' in the classroom. So, the teachers have to 
provide more opportunities for the students to speak in the classroom. By providing the students opportunities to interact with the teacher, the students will apply their language knowledge and also get many opportunities to increase their ability in using English.

When doing teaching practice program (PPL) at SMP N 2 Babalan, the writer found that teaching-learning speaking in English class was dominated by the teacher. The dominance of teacher talk in teaching-learning speaking in the classroom interaction seems to be irrelevant in foreign language teaching that should be focused on student talk, which will make the students active.

Based on the writer's experience above, the writer wants to analyze the percentage, the types of interaction and the dominant characteristic of interaction that the teacher and students do while teaching-learning processs in English class in that school. The analysis of Teaching English in this study focuses on teaching speaking. 


\section{LITERATURE REVIEW}

\section{Interaction}

Interaction is a process through which people act in relation to one another, $\mathrm{tt}$ is what communication is all about (Talat, 2015). Tuan and Nhu (2010) stated that interaction is meaning-focused and carried out to facilitate the exchange of information and prevent communication. Interaction occurs when these objects and events mutually influence one another. Chaudron in Kaur and Tatla (2015) states that interaction is viewed as significant because it is argued that:

1. Only through interaction, the learner can decompose the teaching language structures and derive meaning from classroom events.

2. Interaction gives learners the opportunities to incorporate teaching language structures into their own speech (the scaffolding principles).

3. The meaningfulness for learners of classroom events of any kind, whether thought of as interactive or not will depend on the extent to which communication has been jointly constructed between the teacher and learners.

\section{Classroom Interaction}

Classroom interaction is an interaction between lecturer and students that happens when they participate in the classroom. It means that classroom interaction is all of interactions that occur in the learning and teaching process. 


\section{a. The Types of Classroom Interaction}

Dagarin in Talat (2015) states that there are four types of interaction that occur in the classroom, as the follows:

\section{i. Teacher - learners}

Teacher-learners interaction is established when a teacher talks to the whole class at the same time. He takes the role of a leader or controller and decides about the type and process of the activity. the primary function of such interaction is controlled practising of certain language structures or vocabulary.

\section{ii. Teacher - learner/a group of learners}

Teacher - learner/a group of learners interaction is directed when the teacher talks to the whole class but he points out one student or a group of students to answer the question.It is often used for evaluation of individual students

\section{iii.Learner - learner}

Learner - learner interaction is known as 'pair work' where the student have to work in groups to fulfil their task. Students get an assignment, which they have to finish in pairs. The teacher holds the role of a consultant or adviser, helping when necessary. After the activity, he puts the pairs into a whole group and each pair reports on their work. 


\section{iv. Learners - learners}

Learners - learners interaction is is beneficial to the motivation and encouragement of interaction among students. The students use more language functions in pairs and in group work than in other forms of interaction. As with pair work, the teacher's function here is that of a consultant and individual groups report on their work as a follow-up activity.

\section{Flander's Interaction Analysis Categories System (FIACS) Technique}

According to Amidon and Hough in Shahi(2010) FIACS is currently best known and the most widely used system for analyzing classroom instructional process. It adopts ten types of behavior code to carry out the research of speech interaction between teachers and students and initiates quantitative research of the contemporary classroom observation.

Flander's Interaction Analysis Categories System (FIACS) is a Ten Category System of communication which are said to be inclusive of all communication possibilities. There are seven categories used when the teacher is talking (Teacher talk) that is, accepting feeling, praising and encouraging, accepting students' ideas, asking question, lecturing, giving direction and criticizing and two when the student is talking (Student talk) that is student talk respond and student talk initiation. The tenth category is that of silence or confusio 


\section{RESEARCH METHODOLOGY}

The design of this research is Descriptive Qualitative Design. In this study, the researcher observed teacher and students talk while having a class in teaching and learning process. The researcher involved 1 (one) English teacher and chose three classes, one of grade eight, and two of grade nine. Thus, the total of observation would be three classes. In this research,the researcher used two instruments. The instruments were observation tally sheet and recording (audio and video recording). The researcher used Flander's Interaction Analysis Categories System (FIACS) to analyze the data

\section{Techniques of Data Analysis}

The techniques of analyzing the data will be presented as follows:

1. Coding the verbal interaction based on Flander's Interaction Analysis Categories System (FIACS).

2. Calculating each type of teacher talk and student talk by using the following formula.

$$
\begin{aligned}
C 1 & =\frac{\text { number of } \mathrm{c} 1}{\mathrm{~N}} \times 100 \% \\
C 2 & =\frac{\text { number of } \mathrm{c} 2}{\mathrm{~N}} \times 100 \% \\
C \ldots & =\frac{\text { number of } \mathrm{c} .}{\mathrm{N}} \times 100 \% \\
\text { Where }: \mathrm{C} 1 \quad & : \text { chategory } 1 \\
\mathrm{C} 2 \quad & : \text { chategory } 2
\end{aligned}
$$




$$
\begin{aligned}
& \text { C.. } \quad \text { : chategoy .. } \\
& \mathrm{N} \quad \text { : number of the interaction }
\end{aligned}
$$

3. Plotting the coded data into a matrix. To plot the numbers recorded in Step 1 on a matrix pairs of numbers. The first pair represents one point on the matrix; the second pair represents another point on the matrix, and so on. The matrix consists of ten columns and ten rows. Each column and row represents.

4. Analyzing the matrix In a complete matrix, some areas have tallies than others. A heavier concentration of tallies in a certain area gives information about the characteristic of interaction that occur in the class.

5. Calculating The Teacher Talk and Student Talk. After the researcher got the data from observation sheet of Flander interaction analysis, the researcher would calculate how much the teacher and students talk time in classroom interaction by using the following formula.

\section{a. Teacher Talk.}

$$
\begin{gathered}
T T=\frac{\mathrm{c} 1+\mathrm{c} 2+\mathrm{c} 4+\mathrm{c} 5+\mathrm{c} 6+\mathrm{c} 7}{\mathrm{~N}} \times 100 \% \\
\text { Where }: \text { TT } \quad: \text { Teacher talk } \\
\text { C1 } \quad: \text { chategory } 1 \\
\text { C... } \quad: \text { chategory ... }
\end{gathered}
$$




$$
\mathrm{N} \text { : number of the interaction }
$$

\section{b. Students Talk}

$$
S T=\frac{c 8+c 9}{N} \times 100 \%
$$

$$
\begin{array}{ll}
\text { Where : ST } & \text { : Students talk } \\
\text { C8 } & : \text { chategory } 8 \\
\text { C2 } & : \text { chategory } 9 \\
\text { N } & : \text { number of the interaction }
\end{array}
$$

\section{c. Silence and confusion}

$$
\begin{array}{cl}
S C=\frac{\mathrm{c} 10}{\mathrm{~N}} \times 100 \% \\
\text { Where : } \mathrm{SC} \quad: \text { Silence or Confusion } \\
\mathrm{C} 10 \quad: \text { chategory } 10 \\
\mathrm{~N} \quad \text { : number of the interaction }
\end{array}
$$




\section{RESULT AND DISCUSSION}

\section{Result}

After analyzing the data, observing and calculating the percentage in the classroom interaction in SMP N 2 Babalan, the findings of the result can be presented as folliows:

1. Ten types of interaction in the Flanders Interaction Analysis Category (FIACS) namely, accepting feeling, praising and encouraging, accepting students' ideas, asking question, lecturing, giving direction, criticizing, students talk response, student talk initiation, and silence and confusion appeared while teaching learning process in SMP N 2 Babalan. The percentages of each were $0.41 \%$ for accepting feeling, $9.97 \%$ for praising and encouraging, 0.22 for accepting students' ideas, $26.26 \%$ for asking question, $4.70 \%$ for lecturing, $13.25 \%$ for giving direction, $2.21 \%$ for criticizing, $39.35 \%$ for students talk response, $1.10 \%$ student talk initiation and 1.93 for silence and confusion.

2. The percentages of teacher talk and Student talk in three different classes. The first class, the teacher spent $60.98 \%$ of interaction while students only spent $37.31 \%$ of interaction while teaching-learning process and $1.79 \%$ for silence or confusion. In the second class, the teacher spent $51.62 \%$ of interaction while students spent $47.29 \%$ and silence or confusion $1.08 \%$. In the third class, the teacher spent $66.66 \%$ of interaction while the students spent $33.63 \%$ of interaction and $2.70 \%$. 
3. The most dominant characteristic of interaction that appeared in SMP N 2 Babalan was Content Cross, with $55.13 \%$, means that the teacher focused on asking question and lecturing in classroom activities or giving facts or opinions about content or procedure with her own ideas.

\section{Discussion}

Based on the result, asking question is the highest type of teacher talk by $26.86 \%$ and students talk response is the highest type of student talk by $39.35 \%$. from the result above, the students spoke in the class if the teacher asked them to speak, or spoke in the class just to answer the questions from the teacher. According to Van Lier (1996) in tuan and nhu, this model has been characterized as a "closed, rather than an open, discourse format". Therefore, it makes the lesson less communicative.

After calculating the interaction in the class, the researcher found that teacher talk was still high. The teacher spent $60.98 \%, 51.62 \%$ and $61.15 \%$ in diffrent three classes. Meanwhile the students spent $37.31 \%, 47.29 \%$ and 28.09 $\%$ while teaching learning process. Based on Wright theory (1975) ,the teacher should do no more than 25 percent of the talking in class, and the students should be permitted to do $75 \%$ of the talking. Based on the result, the interaction in the three classes above is not ideal because the teacher spent almost $60 \%$ in teachinglearning process

. The researcher also found that the highest characteristic of interaction of three class was Content Cross, with $55.13 \%$, means that the teacher did more asking question and lecturing in classroom activities. During teaching - learning 
process, the teacher focused on asking questions about the material, she also focused on giving facts or opinion about content or procedure with her own ideas. So, it can be concluded that teaching - learning process of English Subject in SMP N 2 Babalan was still in teacher's dominant activity. Based on the result above, the teacher still need to improve her performance while teaching-learning process and to help students get their goal by giving more opportunities to the students to speak in the class while teaching-learning process.

\section{CONCLUSIONS AND SUGGESTIONS}

\section{Conclusions}

1. All of the types of interaction based on Flanders Interaction Analysis Category System (FIACS) appeared during teaching-learning process in SMP N 2 Babalan. The percentages of each were $0.41 \%$ for accepting feeling, 9.97 $\%$ for praising and encouraging, 0.22 for accepting students' ideas, $26.26 \%$ for asking question, $4.70 \%$ for lecturing, $13.25 \%$ for giving direction, $2.21 \%$ for criticizing, $39.35 \%$ for students talk response, $1.10 \%$ student talk initiation and 1.93 for silence and confusion.

2. The interaction between teacher and students in English classes are not ideal beacause the teacher was dominant than students in teaching- learning process in. The teacher spent $60 \%$ of interaction in the classroom while students only spent $38 \%$ of interaction. 
3. The most dominant characteristic of interaction in SMP $\mathrm{N} 2$ Babalan was ContentCross by $55.13 \%$. It indicates that most of the teaching-learning time was the teacher talk on giving questions and giving the material.

\section{Suggestion}

1. The lowest percentage of teacher talk was accepting students' ideas and the highest was asking question. The lowest percentage of student talk was student talk innitiation and the higest was student talk response. From the result above the teacher only initiated the conversation with a question, and asked a student to answer the question. It is better if the teacher ask the students to extend their point of view about the topic and give positive reinforcement by praising the students when they give their opinions or ideas in order to make the students more active in the class.

2. The percentages of students talk and teacher talk above show that the teacher is still more dominant than the students. The dominance of teacher talk in teaching-learning procces seems to be irrelevant in foreign language teaching that should be focused on student talk, which will make the students active. Based on the result, the teacher should decrease their talking time by providing more opportunities to the students to speak in the class.

3. The most dominant characteristic of interaction in SMP N 2 Babalan was Content Cross by $55.13 \%$. It indicates that most of the teaching-learning time was the teacher talk on giving questions and giving the material. It is better if the teacher not only spend the teaching-learning time by 
explaining the material or asking question to the students about the material, but also can organize some activities for the students to make the classroom interaction more effective. For example, teacher asks the students make a group and give one topic of the material to discuss. After having discussion, each group presents their discussion result in front of the class and the other groups have to respond. It will make the students more active in the class.

\section{REFERENCES}

Amatari , Veronica Odiri. 2015. The Instructional Process: A Review of Flanders' Interaction Analysis in a Classroom Setting, Amassoma. Nigeria (Volume 3, no: 5)

Best and khan. 2007. Research in education.University of illiniois, Chicago.

Chapman, Siobhan. 2006. Thinking About LanguageTheories of English, Macmillan Distribution Ltd. England

Douglas.2000. Teaching Principles an Interactive approach To Language Pendagogy. San Fransisco, California

Getachew, abemayehu.2014.The Ratio Of Teacher Talking Time To Students Talking Time In EFL Classroom: A Case In Six Partner Prepatory Schools Of Haramaya University, Ethiopia .Visakhapatnam, India (Volume 3, no: 5)

Goronga ,Pedzisai. 2013. The Nature and Quality of Classroom Verbsl Interaction: Implications for Primary School Teachers in Zimbabwe. Zimbabwe (Volume 4, no:2) 
J. Davies. 2011. Increasing students' L2 usage:An analysis of teacher talk time and student talk time. University of Birmingham

Jingxia, Liu 1, Thao Le 2.2002.A Case Study on College English Classroom Discourse. 1 Three Gorges University, China

Kamarudin and Mubin. 2012. INFLUENCE OF TEACHER-STUDENT INTERACTION IN THE CLASSROOM BEHAVIOR ON ACADEMIC AND STUDENT MOTIVATION IN TEACHERS' TRAINING INSTITUTE IN MALAYSIA. Malaysia. (Vol 2, No:1)

Kaur and tatla. 2015. Flanders Classroom Interaction Category System As A Tool Of Tteaching.Associate Professor, Department of Education C.S., Punjabi University Patiala. (Volume 2, no:9)

Maurine, et all. 2012. The Nature of Communication Process in Kiswahili LanguageClassrooms.Society of Education, India. ( Volume 3, no:2) 